\title{
Value Analysis Method, Leverage for Cost Reduction and Technological Change in the Electrical Engineering Field
}

\author{
Cristina Mihaela Gheorghe ${ }^{1, *}, \dagger$ Mircea Covrig $^{1}$, Mihai Virgil Popescu ${ }^{2}$ \\ ${ }^{1}$ Faculty of Electrical Engineering, University Politehnica of Bucharest, 313 Splaiul Independentei, Bucharest, 060042, Romania \\ ${ }^{2}$ Electrical Machine Works Bucharest, Romania \\ *Corresponding Author: cristina.gheorghe@upb.ro
}

Copyright (C) 2013 Horizon Research Publishing All rights reserved.

\begin{abstract}
Based on both the manufacturer's perspective (an engineering approach) and the customer's point of view (a marketing approach), the Value Analysis Method can determine both directions to reduce production cost and technological change to a product. The method allows the analysis of the possibilities to reduce manufacturing costs based on a detailed investigation of the current cost of a product. The present paper tackles the implementation of the Value Analysis Method in the manufacturing of electrical motors, with application for the flameproof motors. The authors identified four categories of flameproof motor functions: (a) strong undervalued functions, (b) strong overvalued functions, (c) slightly under / over-valued and (d) proportionately valued functions (by the manufacturer). Hence, the data on the production costs are provided by a domestic (Romanian) producer. It examines the method's potential to create solutions to increase efficiency and effectiveness of the studied motors.
\end{abstract}

Keywords Value Analysis, Cost Reduction, Technological Change, Electrical Engineering, Flameproof Motors

\section{Introduction}

The Value Analysis Method arose when the engineer Lawrence Delos Miles changed the product's approach: from breaking down the product into its component parts to identification of the functions that the product must meet. Hence, he replaced the question "What materials should I buy?" with "What functions need I buy?" [1]. As a result, in 1947, Lawrence Delos Miles developed a systematic method for functional analysis of the product in order to reduce the product' manufacturing cost by eliminating those costs that do not contribute to the operation/value of product. He named the method "value analysis"[1-6].

If applied, the principles of Value Analysis involve the analysis of the product from the external environment, as perceived by the user. Combining the manufacturer' (engineering issues) with the end user's point of view (marketing issues), this approach helps identify ways to reduce the product' cost [7,8]. Moreover, Value Analysis can be used as a method of assessing the quality and technical level of products, being also used in competition analysis $[9,10]$.

A key observation is the need to distinguish between the Value Analysis and the Value Engineering since they are widely used as synonyms. The Value Analysis and the Value Engineering are not two different processes, it is one and the same method applied to two different times of the life cycle of an (industrial) product [1]. When the product is in the design phase and the purpose is to identify the best technical and economic solutions, the value engineering methodology is applied. On the other hand, when the aim is to improve an existing product, the value analysis methodology is applied $[2,4,11]$.

In this paper, the authors evaluate the existing costs of a flameproof motor and consider whether its costs reflect the users' choices. To achieve this objective, a Value Analysis methodology to the flameproof motors is proposed. As a consequence, the authors structured it as follows. First, some illustrative applications of Value Analysis method in various areas are presented. Second, the authors describe, briefly, the proposed phases of the Value Analysis method. The phases of the functional analysis, the technical analysis, the economic analysis and the systemic analysis are summarized. Further, the Value Analysis methodology developed for two opposite flameproof electric motors is presented. The results of the study are analyzed and conclusions drawn.

\section{The Applications of Value Analysis Method. A Brief Literature Review}

The Value Analysis versatility is demonstrated by the variety of its applications. A brief review of the Value Analysis studies highlights the applicability of the method for both products and industrial processes: civil engineering, public services, town planning, public transport, mechanical engineering domain, pharmaceutical industry etc. Value 
analysis concepts can be used both in the large series products and the unique products, the simple products and the high-tech products [12]. The following examples are worth considering:

- renovation and expansion of the library at the Rhode Island School of Design. The application of Value Analysis has improved a facility function according to budget constraints (2007) [13];

- improve selection process for the construction project proposals (2007) [14];

- expansion of the Edmonton' sewer system, Canada (2009) [15];

- expansion of the Kyungboo Express Highway, the main artery between Seoul to Pusan (2010); the use of Value Analysis concepts results in a $50 \%$ project cost reduction [16];

- construction and modernization of the railways West Rail, Hong Kong (2010) [17];

- reduce the energy costs in the Iranian industrial organizations (2010) [18];

- pricing of the electricity in Romania (2001) [19];

- the approach of the sports performance in terms of ergonomics and Value Analysis (2005) [20];

- in the pharmaceutical field, the Value Analysis concepts can be applied to achieve the following objectives: (1) to reduce the production costs by eliminating unnecessary functions of existing products (e.g. for the outer packaging box, the cardboard may be preferred to plastic packaging); (2) to identify other methods of achieving the product's functions (e.g. replacing a substance contained in a synthetic oral drug with a herbal extract less irritating to the stomach) (2008) [21];

- redesigning a jaw crusher (2009) [22];

- designing/redesigning of an organization's management system (2010) [23];

- diminish cost of the galvanization process (2012) [10].

Despite the large number of publications, the Value Analysis applications in electrical engineering are few. Ion Ioniță (2000) points out on reducing the manufacture costs of electric motors at the "Electromotor" (Timişoara, Romania), based on the Value Analysis, but in the 70s [2]. Present study aims at developing this particular domain. An adaptation of Value Analysis methodology based on the profile of the electric machines is proposed.

\section{The Phases of the Value Analysis Method}

In A brief relevant literature highlights different Value Analysis methodologies. Most of the time, Value Analysis phases are overlapping with those of the Value Engineering method. Even if called differently, all methodologies have the same key activities.

There are many interpretations of the Value Analysis method, the name and the number of phases varying from one author to another. For instance, L. W. Crum (1976) describes a seven-phase process of the Value Engineering: (1) the information phase (2) the speculation/creative phase, (3) the evaluation phase, (4) the planning phase, (5) the execution phase, (6) the report phase and (7) the implementation phase [1]. On the other hand, Sunil Jauhar (2012), in order to decrease cost of the galvanization process, has applied an eight-phase Value Analysis method: (1) the orientation phase (2) the information phase (3) the function phase (4) the creative phase (5) the evaluation phase (6) the presentation phase (7) the implementation phase (8) the follow up phase [10].

The present research deals with the Value Analysis in order to investigate the current production cost of a two different flameproof motors. The authors developed a four-stage methodology: (1) the functional analysis phase, (2) the technical analysis phase, (3) the economic analysis phase and (4) the systemic analysis phase. This methodology is based on Ioniță (2000) [2] and on the Romanian standard STAS 11272/2-79 Value Analysis. The application of the method to the products [24].

\subsection{The Functional Analysis Phase}

The functional analysis phase implies: (1) setting up the product's functions from the end-user perspective; (2) calculating the weight value of the product's functions in the use-value of the product $[1,2,8,11,23]$.

Value Analysis principles involve the analysis of the product from the external environment, as perceived by its user. In view of setting up the product's functions correctly, the product was considered in terms of energy exchanges with external environment $[7,8]$.

The calculation the weight value of the product's functions is based on the determination of the level of importance. In order for the functions evaluation to reflect the reality, the authors applied the methodology for calculating the level of importance of the functions, proposed and described in [8].

\subsection{The Technical Analysis Phase}

Technical analysis is the correlation between product's functions with the technical parameters and the structural characteristics of the product $[2,11]$. This phase implies: (1) identification of the physical quantities that contribute to fulfilling each of the product's function; (2) allocation of the suitable product parts (components, subassemblies) to each of the product's functions. The characteristics (the type) of the product's parts result in variations of the physical quantities and further in variation of the functions fulfillment. In conclusion, technical analysis depends exclusively on the product structure analysis. The standard method is exposed in $[1,2,22,25,26,27]$.

\subsection{The Economic Analysis Phase}


Economic analysis involves the determination of the weight cost value of each of the product's functions in the manufacturing cost of the product, corresponding to its importance to the end-user. Accuracy of the cost functions depends on how these are established: the cost of raw materials and supplies, the cost of labor and the administration costs. Authors proposed the Value Analysis to waive calculation of administration costs, by considering a one percent increase which can differ from one organization to another.

Determination of the cost functions can be done by several methods $[1,2]$. In this study, the authors used the method of allocation of costs on the product' functions proportional with their level of importance. This method is easy to apply and was verified empirically [2]. The method requires [2,7]:

- identification of all parts of the product;

- identification of all operations needed for product manufacturing;

- material costs of the product parts;

- costs of the operations ( the labor cost);

- allocation of the parts on each product's function;

- allocation of the material costs and labor costs on each of the product's functions;

- the weight value of the product's functions in the use-value of the product (the results of the functional analysis phase).

- Determination of the cost functions implies [2,7]:

- setting the cost of (raw) materials for each part of the product;

- calculating a relative importance level for each part of the product, as sum of all importance levels of the functions for which the product part is allocated;

- calculating the cost per relative level of importance;

- calculating the material cost of each function.

The process is repeated for the labor cost of each function. The sum of material cost and labor cost for each function represents the cost of the function.

Sum of all function costs represents the manufacturing cost of the product and must be equal to the sum of all costs of the product parts and operations (labor costs) considered.

\subsection{The Systemic Analysis Phase}

The relationship between the cost and the level of importance for each product function is investigated within the systemic analysis phase. It aims to identify the functions whose fulfillment costs too much compared to their contribution to the end-value of the product $[2,7,11]$. The principle behind this phase is the proportionality between the weight value of the each function in the use-value of the product and the weight value of each function cost in the manufacturing cost of the product: a function with the weight value zero in use-value of the product must also cost zero. Proportionality analysis can be performed using the graphics method $[2,7,11]$.

\section{The Case study. Results and Discussions}

The case study subjects are two flameproof motors, named M1 and M2, with the different /opposite dimensions. The two motors were designed according to the manufacturer's internal classifications:

- M1: ASA $132 \mathrm{M}-4,7,5 \mathrm{~kW} / 1500 \mathrm{rpm}, 4 / 7 \mathrm{~V}, \mathrm{~B} 3$

- M2: ASA $225 \mathrm{~S}-4,37 \mathrm{~kW} / 1500 \mathrm{rpm}, 4 / 7 \mathrm{~V}, \mathrm{~B} 3$

Information on the constructive parts, the production costs and the labor cost of flameproof motors was provided by a domestic (Romanian) producer.

Table 1. The functional hierarchy of a flameproof electrical motor [8]

\begin{tabular}{|c|c|c|c|}
\hline No & $\begin{array}{c}\text { The } \\
\text { function } \\
\text { label }\end{array}$ & The description of the function & $\begin{array}{c}\text { The } \\
\text { weight } \\
\text { value } \\
{[\%]}\end{array}$ \\
\hline 1 & F21 & It provides the starting torque & 7.59 \\
\hline 2 & F22 & It limits the starting current & 7.31 \\
\hline 3 & F23 & It provides the rated torque & 7.01 \\
\hline 4 & F11 & $\begin{array}{l}\text { It provides conditions for the } \\
\text { power supply connection }\end{array}$ & 5.70 \\
\hline 5 & F12 & $\begin{array}{l}\text { It provides the mechanical } \\
\text { coupling conditions }\end{array}$ & 5.37 \\
\hline 6 & F32 & $\begin{array}{l}\text { It provides the electrical } \\
\text { protection of the user }\end{array}$ & 5.01 \\
\hline 7 & F24 & $\begin{array}{l}\text { It provides the established } \\
\text { minimum efficiency }(\eta)\end{array}$ & 5.00 \\
\hline 8 & F31 & $\begin{array}{l}\text { It provides the ground fault } \\
\text { protection of the user }\end{array}$ & 4.95 \\
\hline 9 & F41 & $\begin{array}{l}\text { It provides waterproof /dustproof } \\
\text { options }\end{array}$ & 4.71 \\
\hline 10 & F34 & $\begin{array}{l}\text { It provides the cooling / the } \\
\text { extinction of any operation sparks }\end{array}$ & 4.60 \\
\hline 11 & F26 & It provides the maximum torque & 4.30 \\
\hline 12 & F42 & $\begin{array}{l}\text { It provides the extreme } \\
\text { temperature operation }\end{array}$ & 3.94 \\
\hline 13 & F16 & $\begin{array}{l}\text { It provides the heat evacuation (to } \\
\text { the outside) }\end{array}$ & 3.90 \\
\hline 14 & F33 & $\begin{array}{l}\text { It provides the mechanical } \\
\text { protection of the user }\end{array}$ & 3.82 \\
\hline 15 & F13 & $\begin{array}{l}\text { It provides the mechanical grip of } \\
\text { the machine }\end{array}$ & 3.58 \\
\hline 16 & F25 & $\begin{array}{l}\text { It provides the full load power } \\
\text { factor }\end{array}$ & 3.55 \\
\hline 17 & F14 & It provides the handling ways & 3.24 \\
\hline 18 & F43 & It provides the repair options & 3.13 \\
\hline 19 & F44 & $\begin{array}{c}\text { It provides the identification } \\
\text { options }\end{array}$ & 2.95 \\
\hline 20 & F35 & It provides the noise level limit & 2.47 \\
\hline 21 & F46 & It provides the warranty services & 2.35 \\
\hline 22 & F15 & $\begin{array}{l}\text { It provides the possibilities for } \\
\text { transportation }\end{array}$ & 1.99 \\
\hline 23 & F36 & $\begin{array}{l}\text { It provides the possibilities for the } \\
\text { recycling of used materials }\end{array}$ & 1.92 \\
\hline 24 & F45 & $\begin{array}{c}\text { It provides the aesthetic } \\
\text { characteristics }\end{array}$ & 1.61 \\
\hline \multicolumn{3}{|c|}{ TOTAL (the use value) } & 100.00 \\
\hline
\end{tabular}




\subsection{The Functional Analysis Phase}

Based on the methodology proposed and described by the authors in [8], 24 functions of the flameproof motor were identified, evaluated and ranked as shown in Table 1.

Given the complexity of the product, the authors considered three categories of users to evaluate the functions of the flameproof motor:

- operations engineers and technicians

- engineers - the electric machines designer

- academics (professors and researchers) specialized in electrical machines.

\subsection{The Technical Analysis Phase}

Based on information provided by the manufacturer of the two motors, the authors established the structure of the flameproof motor consisting of 23 parts / subassemblies see Table 2, and 23 activities - see Table 3.

Table 2. Parts of the flameproof motor. Source: adapted domestic (Romanian) producer, March 10, 2011

\begin{tabular}{|c|c|}
\hline The parts label & The parts (subassembly) name \\
\hline $\mathrm{R} 1$ & terminal box \\
\hline $\mathrm{R} 2$ & terminal box cover \\
\hline R3 & finished/trimmed frame \\
\hline R4 & eyebolt \\
\hline $\mathrm{R} 5$ & grounding bolt \\
\hline R6 & machine tag \\
\hline R7 & fan \\
\hline $\mathrm{R} 8$ & fan housing \\
\hline R9 & end shields \\
\hline R10 & ball bearings \\
\hline $\mathrm{R} 11$ & stator stack with slots (the stator core) \\
\hline $\mathrm{R} 12$ & stator windings (copper) \\
\hline R13 & conductor connections (winding terminals) \\
\hline $\mathrm{R} 14$ & insulations + impregnation \\
\hline $\mathrm{R} 15$ & thermistors, moisture resistors \\
\hline R16 & rotor stack with laminations (the rotor core) \\
\hline R17 & squirrel cage winding (aluminum) \\
\hline $\mathrm{R} 18$ & shaft \\
\hline R19 & coating paint \\
\hline $\mathrm{R} 20$ & motor wrapping \\
\hline $\mathrm{R} 21$ & rotor' mounting parts \\
\hline $\mathrm{R} 22$ & stator' mounting parts \\
\hline $\mathrm{R} 23$ & parts required for final mounting \\
\hline
\end{tabular}

Table 3. Operations of the flameproof motor. Source: adapted domestic
(Romanian) producer, March 10, 2011

\begin{tabular}{|c|c|}
\hline $\begin{array}{c}\text { The operations } \\
\text { label }\end{array}$ & The operations (labor) name \\
\hline M1 & mounting the terminal box \\
\hline M2 & fixing the terminal box cover \\
\hline M3 & mounting the frame \\
\hline M4 & fixing the eyebolt \\
\hline M5 & fixing the grounding bolt \\
\hline M6 & fixing the machine tag \\
\hline M7 & mounting the fan \\
\hline M8 & mounting the fan cover \\
\hline M9 & mounting the end shields \\
\hline M10 & attaching the bearings \\
\hline M11 & mounting the stator core \\
\hline M12 & winding and forming the coils \\
\hline M13 & connecting the coils and terminals \\
\hline M14 & insulation and impregnation procedures \\
\hline M15 & installing the thermistors \\
\hline M16 & assembling the rotor core \\
\hline M17 & die casting the aluminum squirrel cage \\
\hline M18 & mounting the shaft \\
\hline M19 & painting the motor \\
\hline M20 & Assembling the motor \\
\hline M21 & assembling the rotor \\
\hline M22 & assembling the stator \\
\hline M23 & motor final assembling \\
\hline
\end{tabular}

Based on the manufacturer's and the user's point of view, each function of the flameproof motor was defined and evaluated. In Table 4 is the allocation of the suitable product parts (components, subassemblies) to each of the product's functions.

Table 4. T he allocation of the suitable product parts to each of the product's functions

\begin{tabular}{|c|c|c|}
\hline $\begin{array}{l}\text { The } \\
\text { function } \\
\text { label }\end{array}$ & $\begin{array}{l}\text { The description of the } \\
\text { function }\end{array}$ & The flameproof parts \\
\hline F11 & $\begin{array}{l}\text { It provides conditions for } \\
\text { the power supply } \\
\text { connection }\end{array}$ & $\begin{array}{c}\text { terminal box (R1); } \\
\text { terminal box (cover R2); } \\
\text { conductor } \\
\text { connections(R13); }\end{array}$ \\
\hline F12 & $\begin{array}{l}\text { It provides the mechanical } \\
\text { coupling conditions }\end{array}$ & $\begin{array}{c}\text { shaft (R18); } \\
\text { ball bearings (R10); } \\
\text { end shields (R9); }\end{array}$ \\
\hline F13 & $\begin{array}{l}\text { It provides the mechanical } \\
\text { grip of the machine }\end{array}$ & finished frame (R3); \\
\hline F14 & $\begin{array}{l}\text { It provides the handling } \\
\text { ways }\end{array}$ & $\begin{array}{c}\text { finished frame (R3); } \\
\text { eyebolt (R4); }\end{array}$ \\
\hline F15 & $\begin{array}{l}\text { It provides the possibilities } \\
\text { for transportation }\end{array}$ & $\begin{array}{c}\text { eyebolt (R4); } \\
\text { motor wrapping (R20); }\end{array}$ \\
\hline F16 & It provides the heat & finished frame (R3); \\
\hline
\end{tabular}




\begin{tabular}{|c|c|c|}
\hline & evacuation (to the outside) & $\begin{array}{c}\text { fan (R7); } \\
\text { end shields (R9); }\end{array}$ \\
\hline $\mathrm{F} 21$ & $\begin{array}{l}\text { It provides the starting } \\
\text { torque }\end{array}$ & $\begin{array}{l}\text { stator windings(R12)1 } \\
\text { squirrel cage (R17)2 }\end{array}$ \\
\hline F22 & It limits the starting current & squirrel cage (R17) \\
\hline F23 & It provides the rated torque & $\begin{array}{l}\text { stator windings }(\mathrm{R} 12)^{1} \\
\text { squirrel cage }(\mathrm{R} 17)^{2}\end{array}$ \\
\hline F24 & $\begin{array}{l}\text { It provides the established } \\
\text { minimum efficiency }(\eta)\end{array}$ & $\begin{array}{c}\text { stator core }(\mathrm{R} 11) \\
\text { stator windings(R12)3; } \\
\text { squirrel cage }(\mathrm{R} 17) 4\end{array}$ \\
\hline F25 & $\begin{array}{l}\text { It provides the full load } \\
\text { power factor }\end{array}$ & $\begin{array}{l}\text { stator core (R11); } \\
\text { rotor core (R16); }\end{array}$ \\
\hline F26 & $\begin{array}{l}\text { It provides the maximum } \\
\text { torque }\end{array}$ & $\begin{array}{l}\text { stator windings }(\mathrm{R} 12)^{1} ; \\
\text { squirrel cage }(\mathrm{R} 17)^{2} ;\end{array}$ \\
\hline F31 & $\begin{array}{l}\text { It provides the ground fault } \\
\text { protection of the user }\end{array}$ & $\begin{array}{l}\text { grounding bolt (R5); } \\
\text { insulations } \\
\text { impregnation (R14); }\end{array}$ \\
\hline F32 & $\begin{array}{l}\text { It provides the electrical } \\
\text { protection of the user }\end{array}$ & $\begin{array}{l}\text { insulations } \\
\text { impregnation (R14); } \\
\text { stator windings (R12); } \\
\end{array}$ \\
\hline F33 & $\begin{array}{l}\text { It provides the mechanical } \\
\text { protection of the user }\end{array}$ & $\begin{array}{l}\text { finished frame (R3); } \\
\text { fan housing (R8); }\end{array}$ \\
\hline F34 & $\begin{array}{l}\text { It provides the cooling / the } \\
\text { extinction of any operation } \\
\text { sparks }\end{array}$ & $\begin{array}{l}\text { terminal box (R1) } \\
\text { terminal box cover (R2); } \\
\text { end shields (R9); }\end{array}$ \\
\hline F35 & $\begin{array}{l}\text { It provides the noise level } \\
\text { limited }\end{array}$ & $\begin{array}{l}\text { stator core (R11); } \\
\text { ball bearings (R10); }\end{array}$ \\
\hline F36 & $\begin{array}{l}\text { It provides the possibilities } \\
\text { for recycling of used } \\
\text { materials }\end{array}$ & $\begin{array}{l}\text { stator core }+ \text { stator } \\
\text { windings }+ \text { conductor } \\
\text { connections (R11, R12, } \\
\text { R13); } \\
\text { rotor core + squirrel cage } \\
\text { winding (R16, R17); }\end{array}$ \\
\hline F41 & $\begin{array}{l}\text { It provides waterproof } \\
\text { /dustproof options }\end{array}$ & $\begin{array}{l}\text { finished frame (R3); } \\
\text { end shields (R9); } \\
\text { terminal box (R1); } \\
\text { terminal box cover (R2); }\end{array}$ \\
\hline F42 & $\begin{array}{l}\text { It provides the extreme } \\
\text { temperature operation }\end{array}$ & $\begin{array}{l}\text { thermistors }+ \text { moisture } \\
\text { resistors (R15); }\end{array}$ \\
\hline F43 & $\begin{array}{l}\text { It provides the repair } \\
\text { options }\end{array}$ & $\begin{array}{l}\text { finished frame (R3); } \\
\text { end shields (R9); } \\
\text { fan housing (R8); } \\
\text { rotor' mounting parts } \\
\text { (R21); } \\
\text { stator' mounting parts } \\
\text { (R22); } \\
\text { Parts required for final } \\
\text { mounting (R23); }\end{array}$ \\
\hline F44 & $\begin{array}{l}\text { It provides the identification } \\
\text { options }\end{array}$ & $\begin{array}{l}\text { finished frame (R3); } \\
\text { coating paint (R19); } \\
\text { machine tag (R6); } \\
\text { motor wrapping (R20); }\end{array}$ \\
\hline
\end{tabular}

1 number and distribution of spires

2number of bars

3 section and conductor material

4 section and conductor material (cage bars)

\begin{tabular}{|c|l|l|}
\hline F45 & $\begin{array}{l}\text { It provides the aesthetic } \\
\text { characteristics }\end{array}$ & $\begin{array}{l}\text { finished frame (R3); } \\
\text { end shields (R9); } \\
\text { coating paint(R19); } \\
\text { fan housing (R8); }\end{array}$ \\
\hline F46 & $\begin{array}{l}\text { It provides the warranty } \\
\text { services }\end{array}$ & $\begin{array}{l}\text { insulations } \\
\text { impregnation (R14); } \\
\text { ball + bearings (R10; } \\
\text { terminal box (R1). }\end{array}$ \\
\hline
\end{tabular}

\subsection{The Economic Analysis Phase}

Calculation of the functions costs requires data on the cost of the motors parts and labor. Due to privacy, Table 5 presents only the weights value of the costs in the total cost and not the actual costs of the parts and labor. These weights were calculated by the authors based on real costs existing in March 2011.

Table 5. The weight value of the cost of parts and labor in the manufacturing cost for motors M1 and M2

\begin{tabular}{|c|c|c|}
\hline Labels of parts and labor & $\begin{array}{l}\text { M1 } \\
{[\%]}\end{array}$ & $\begin{array}{l}\text { M2 } \\
{[\%]}\end{array}$ \\
\hline $\mathrm{R} 1+\mathrm{M} 1$ & 14.39 & 10.51 \\
\hline $\mathrm{R} 2+\mathrm{M} 2$ & 1.62 & 0.99 \\
\hline $\mathrm{R} 3+\mathrm{M} 3$ & 15.18 & 19.35 \\
\hline $\mathrm{R} 4+\mathrm{M} 4$ & 0.35 & 0.31 \\
\hline R5+M5 & 0.22 & 0.10 \\
\hline R6+M6 & 0.13 & 0.04 \\
\hline $\mathrm{R} 7+\mathrm{M} 7$ & 0.16 & 1.42 \\
\hline $\mathrm{R} 8+\mathrm{M} 8$ & 1.06 & 1.29 \\
\hline R9+M9 & 6.03 & 5.41 \\
\hline $\mathrm{R} 10+\mathrm{M} 10$ & 2.82 & 3.71 \\
\hline $\mathrm{R} 11+\mathrm{M} 11$ & 11.69 & 12.98 \\
\hline $\mathrm{R} 12+\mathrm{M} 12$ & 17.42 & 20.46 \\
\hline $\mathrm{R} 13+\mathrm{M} 13$ & 0.94 & 1.35 \\
\hline $\mathrm{R} 14+\mathrm{M} 14$ & 5.54 & 2.48 \\
\hline $\mathrm{R} 15+\mathrm{M} 15$ & 6.01 & 2.98 \\
\hline $\mathrm{R} 16+\mathrm{M} 16$ & 5.83 & 6.12 \\
\hline $\mathrm{R} 17+\mathrm{M} 17$ & 2.30 & 2.00 \\
\hline $\mathrm{R} 18+\mathrm{M} 18$ & 2.61 & 2.98 \\
\hline R19+M19 & 0.71 & 0.41 \\
\hline $\mathrm{R} 20+\mathrm{M} 20$ & 0.30 & 0.14 \\
\hline $\mathrm{R} 21+\mathrm{M} 21$ & 2.50 & 3.09 \\
\hline $\mathrm{R} 22+\mathrm{M} 22$ & 1.14 & 0.57 \\
\hline $\mathrm{R} 23+\mathrm{M} 23$ & 1.05 & 1.32 \\
\hline Product cost & 100.00 & 100.00 \\
\hline
\end{tabular}

Since the distribution of the parts and the operations/labor on functions is the same, the determination of the functions cost was achieved together and not separately, for the parts and for the labor respectively.

Table 6 illustrates the weights value of the functions cost 
based on the allocation of costs on the product's functions proportional with their level of importance [2,7]. Authors used the method of allocation of costs on the product' functions proportional with their level of importance [2]. M1 is the low power/small dimensions flameproof motor, and M2 is the high power/large dimensions flameproof motor.

Table 6. The weight value of the cost of product's functions in the manufacturing cost for motors M1 and M2

\begin{tabular}{|c|c|c|c|}
\hline \multirow{2}{*}{$\begin{array}{c}\text { The } \\
\text { function } \\
\text { label }\end{array}$} & The description of the function & \multicolumn{2}{|c|}{$\begin{array}{c}\text { The weight value of } \\
\text { cost function }\end{array}$} \\
\cline { 3 - 4 } & & $\mathrm{M} 1$ & $\mathrm{M} 2$ \\
\hline F11 & $\begin{array}{c}\text { It provides conditions for the } \\
\text { power supply connection }\end{array}$ & 6.04 & 4.83 \\
\hline F12 & $\begin{array}{c}\text { It provides the mechanical } \\
\text { coupling conditions }\end{array}$ & 5.48 & 6.19 \\
\hline F13 & $\begin{array}{c}\text { It provides the mechanical grip } \\
\text { of the machine }\end{array}$ & 2.01 & 2.57 \\
\hline F14 & It provides the handling ways & 2.04 & 2.52 \\
\hline F15 & $\begin{array}{c}\text { It provides the possibilities for } \\
\text { transportation }\end{array}$ & 0.26 & 0.17 \\
\hline F16 & $\begin{array}{c}\text { It provides the heat evacuation } \\
\text { (to the outside) }\end{array}$ & 3.37 & 5.13 \\
\hline F21 & It provides the starting torque & 5.65 & 6.47 \\
\hline F22 & It limits the starting current & 0.51 & 0.44 \\
\hline F23 & It provides the rated torque & 5.22 & 5.98 \\
\hline F24 & $\begin{array}{r}\text { It provides the established } \\
\text { minimum efficiency }(\eta)\end{array}$ & 8.24 & 9.28 \\
\hline
\end{tabular}

\begin{tabular}{|c|c|c|c|}
\hline F25 & $\begin{array}{l}\text { It provides the full load power } \\
\text { factor }\end{array}$ & 6.99 & 7.54 \\
\hline F26 & It provides the maximum torque & 3.20 & 3.67 \\
\hline F31 & $\begin{array}{l}\text { It provides the ground fault } \\
\text { protection of the user }\end{array}$ & 2.45 & 1.09 \\
\hline F32 & $\begin{array}{l}\text { It provides the electrical } \\
\text { protection of the user }\end{array}$ & 2.25 & 1.01 \\
\hline F33 & $\begin{array}{l}\text { It provides the mechanical } \\
\text { protection of the user }\end{array}$ & 2.62 & 3.32 \\
\hline F34 & $\begin{array}{l}\text { It provides the cooling / the } \\
\text { extinction of any operation } \\
\text { sparks }\end{array}$ & 5.50 & 4.16 \\
\hline F35 & $\begin{array}{l}\text { It provides the noise level } \\
\text { limited }\end{array}$ & 2.91 & 3.38 \\
\hline F36 & $\begin{array}{l}\text { It provides the possibilities for } \\
\text { recycling of used materials }\end{array}$ & 5.43 & 6.04 \\
\hline $\mathrm{F} 41$ & $\begin{array}{l}\text { It provides waterproof } \\
\text { /dustproof options }\end{array}$ & 8.29 & 7.64 \\
\hline $\mathrm{F} 42$ & $\begin{array}{l}\text { It provides the extreme } \\
\text { temperature operation }\end{array}$ & 6.01 & 2.98 \\
\hline F43 & It provides the repair options & 7.65 & 8,41 \\
\hline $\mathrm{F} 44$ & $\begin{array}{l}\text { It provides the identification } \\
\text { options }\end{array}$ & 2.43 & 2.50 \\
\hline F45 & $\begin{array}{c}\text { It provides the aesthetic } \\
\text { characteristics }\end{array}$ & 1.77 & 1.92 \\
\hline F46 & $\begin{array}{c}\text { It provides the warranty } \\
\text { services }\end{array}$ & 3.65 & 2.75 \\
\hline \multicolumn{2}{|r|}{ TOTAL } & 100.00 & 100.00 \\
\hline
\end{tabular}

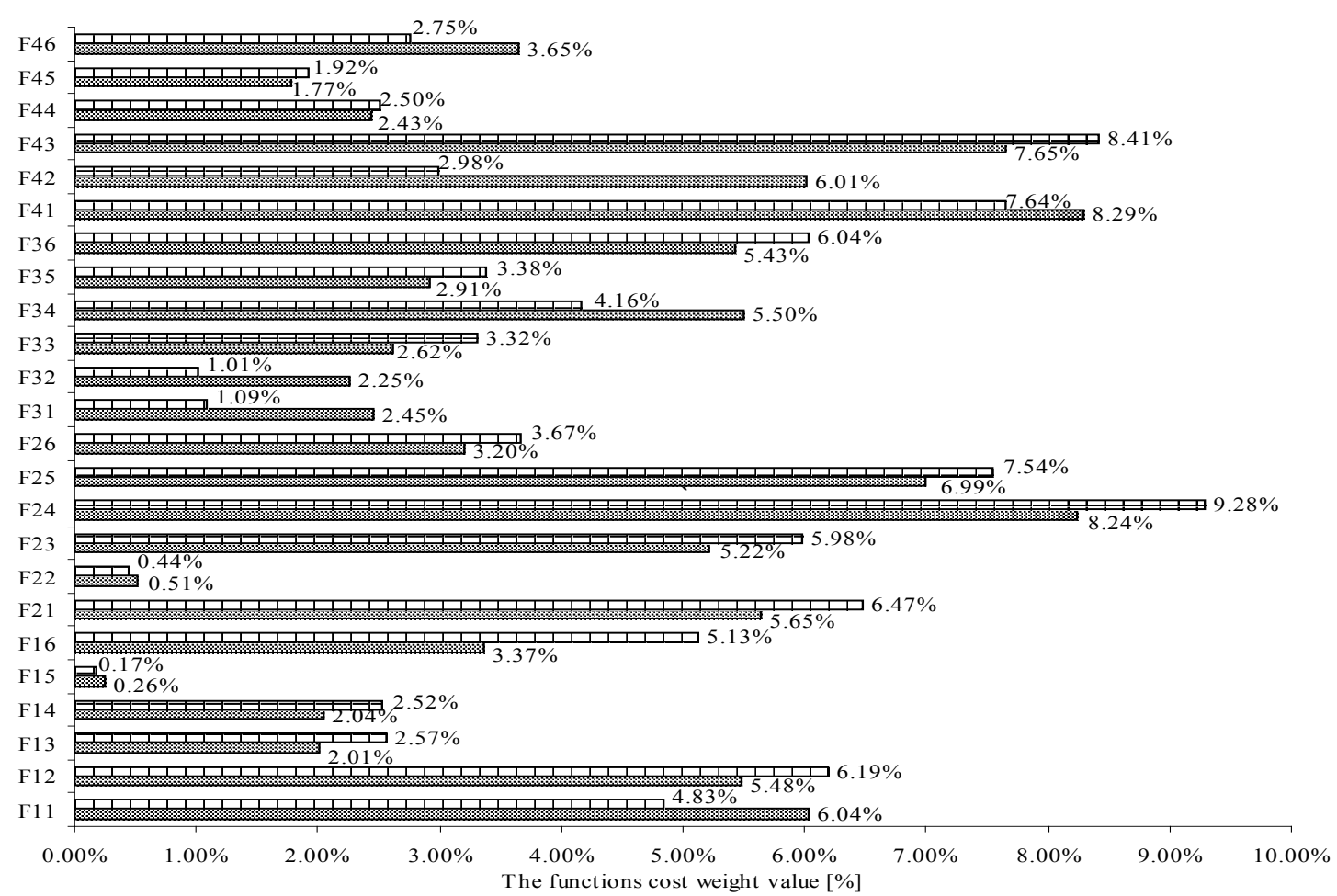

M1 민

Figure 1. Comparison of costs for each function within the total cost for M1 and M2 
The three most expensive functions are: F41 (It provides waterproof /dustproof options), F24 (It provides the established minimum efficiency $(\eta)$ ) and F43 (It provides the repair options). The place in the ranking of these functions varies slightly from one motor to another. For M1, the low power/small dimensions flameproof motor, the F41 function fulfillment has the highest weight value in the manufacturing cost $\left(R c_{F 41}=8.29 \%\right)$. Follows the F24 function $\left(R c_{F 24}=8.24 \%\right)$ and then the F43 function $\left(R c_{F 43}=7.65 \%\right)$, see Table 6 and Figure 1.

On the other hand, for the M2, the high power/large dimensions flameproof motor, the most expensive function is F24 $\left(R c_{F 24}=9.28 \%\right)$ followed by $\mathrm{F} 43$ function $\left(R c_{F 43}=8.41 \%\right)$ and $\mathrm{F} 41$ function $\left(R c_{F 41}=7.64 \%\right)$. It can be noticed that for the small dimensions motor, the cost of the function increases which constitutes the relationship between the motor and its environment (the F41 function). In the case of the large dimensions motor, the performance is achieved by the most expensive function (the F24 function).

With regard to the cheapest functions, for both motors considered, M1 and M2, F22(It limits the starting current) ranks before F15(It provides the possibilities for transportation). What varies from one motor to another is the weight value of the cost of functions: for M1, the low power/small dimensions flameproof motor, $R c_{F 22}=0.51 \%$ and $R c_{F 15}=0.26 \%$, and for $\mathrm{M} 2$, the high power/large dimensions flameproof motor, $R c_{F 22}=0.44 \%$ and $R c_{F 15}=0.17 \%$, see Table 6 and Figure 1 .

\section{The Systemic Analysis Phase}

The application of the principle of proportionality for both M1 and M2 motors is illustrated graphically in Figure 2 and in Figure 3.

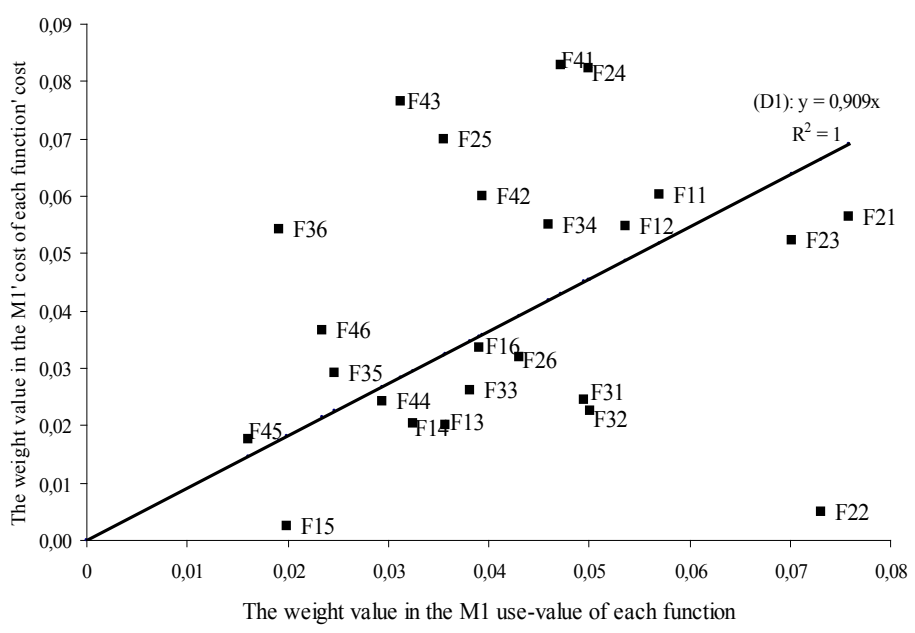

Figure 2. Graphical representation of the 24 functions considered above according to the regression line for M1

A key observation is the importance of the functions expressed as total use value for the user and, for the manufacturer, the cost of production given by the cost of the functions (materials, equipment and technologies used, construction and technological solutions too expensive as compared to other alternatives).

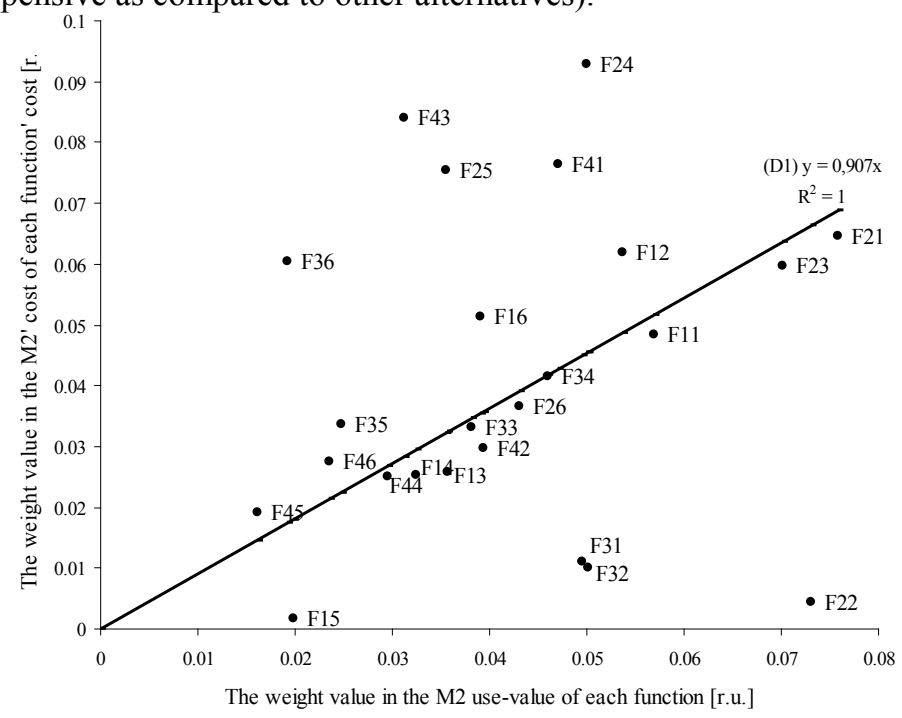

Figure 3. Graphical representation of the 24 functions considered above according to the regression line for M2 
Based on the analysis of the two graphics, Figure 2 and Figure 3, the authors identified four categories of flameproof motor functions:

(a) strong undervalued functions by the manufacturer the functions whose graphical representation is located significantly below the regression line (D1 line, see Figure 2 and Figure 3);

(b) strong overvalued functions by the manufacturer - the functions whose graphical representation is located significantly above the regression line (D1 line, see Figure 2 and Figure 3);

(c) slightly under/over-valued by the manufacturer - the functions whose graphical representation is located near the regression line (D1 line, see Figure 2 and Figure 3);

(d) proportionally valued functions by the manufacturer the functions whose graphical representation is located on the regression line (D1 line, see Figure 2 and Figure 3).

The strong undervalued function by the manufacturer is that function that has high importance to the end-user and the low cost of fulfilling it (the low cost of the function fulfillment would suggest it is overlooked by the manufacturer). Graphically, are those functions positioned significantly below the regression line (D1).

The strong overvalued function by the manufacturer is the function that has low importance to the end-user and the high cost of fulfilling it (the high cost of the function fulfillment would suggest a higher importance for the manufacturer). Graphically, are those functions positioned significantly above the regression line (D1).

For the M1, the low power/small dimensions flameproof motor, see Figure 2, the F22, F23, F21, F32, F33, and F15 functions are strong undervalued functions by the manufacturer. It is easily observed that the most undervalued function is the F22 functions (It limits the starting current). In other words, the end-user assigns it a significant higher importance/value (second place in the user preferences, see Table 1) compared to the weight value of, see Table 6 . In practice, the fulfillment of this function would allow an increase in cost because of the need to meet the user's requirements. The same happens to the F23 and F21 functions. These are on the first place and on the third place in the hierarchy of user importance, see Table 1, and are positioned below the regression line, but closer to it, see Figure 2.

The second category is the strong overvalued functions by the manufacturer: F24, F25, F36, F41 and F43 functions. Within this category there are more subgroups according to the importance for the end-user. For instance, the F24 function is the most expensive function and also very important for a motor. In spite of this, it is ranked only 7 th in the hierarchy of user importance. This could mean that the users are not aware of the importance of the function fulfillment.

Functions proportionately valued by the manufacturers, graphically represented on the regression line (D1 line, see Figure 2) are: the F16 function (It provides the heat evacuation) and the F44 (It provides the identification options).

The remaining functions can be easily assigned to slightly under/over-valued by the manufacturer category, right near a D1 line, see Figure 2.

In the case of M2, the high power/large dimensions flameproof motor, see Figure 3, the authors identified the following:

- the F22 (It limits the starting current) and the F15 (It provides the possibilities for transportation) are the strongest undervalued functions by the manufacturer;

- among the strong overvalued functions by the manufacturer F24, F25, F36, F41 and F43 functions stand out;

- the F33, F34 and F44 are proportionately valued functions by the manufacturer; in spite of the expectations from the F44 function (It provides the identification options), due to its low importance to the user, the Value Analysis results show that it is well designed;

- the remaining functions are slightly under/over-valued by the manufacturer, right near a D1 line, see Figure 3.

The choice of the two very different motors (the M1, the low power/small dimensions flameproof motor and the M2, the high power/large dimensions flameproof motor) helps the authors generalize the study results. When analyzed, the results for M1 versus M2, despite some small differences, the conclusions are the same for both motors. Consequently, it could be stated that the results of Value Analysis application for the flameproof motor domain allows generalization.

Determination of the undervalued or overvalued functions by the manufacturer for the two flameproof motors emphasizes two main areas of optimization: (a) increase the overall use-value of the product or (b) reduction the product's functions cost. The first direction, increasing the overall use-value of the product, is difficult to achieve, because it highly depends on: the user's perception and preferences, the number and the type of competing products, and not least, the industrial development level. Generally, one possibility of optimization is the marketing activity aimed at increasing the product's visibility or changing the user preferences. The second direction, reduction of the cost of the product' functions can be done by changing the quantity and the type of material used, the design, technology etc.

\section{Conclusions}

The Value Analysis Method allows the analysis of the possibilities to reduce manufacturing costs based on detailed investigation of the current cost of a product.

The main novelty of the paper is the developing of the Value Analysis methodology for electrical machines field. The Value Analysis application for the two flameproof 
motors revealed four categories of a product' functions: strong undervalued functions; strong overvalued functions; slightly under / over-valued and proportionately valued functions by the manufacturer. The results could be generalized for whole flameproof motors category.

It identified two possible directions of any product optimization: increasing the overall use-value of the product and cost reduction of the product's functions. The first direction, dependent on the market perception and the users' preferences, is preferred and carried out by marketers. The second direction can be approached by engineers by changing the amount of material used, the technology, the design etc.

The value of the study consists in extending of the Value Analysis Method in the electrical engineering field. By pooling technical constraints to the requirements of users, the method offers potential for both the cost reduction of production as well as for technological changes.

\section{REFERENCES}

[1] L. W. Crum. Value Engineering, Editura Tehnică, Bucharest, 1976 (in Romanian)

[2] Ion Ioniță. (2000) Value Engineering, Editura Economică, Bucharest, 2000 (available only in Romanian)

[3] Anil Kumar Mukhopadhyaya. Value engineering mastermind: from concept to value engineering certification, Response Books, Sage Publications, New Delhi, 2008

[4] R. B. Sperling. Understanding value engineering. It's much more than a set of cost-cutting measures. IIE Solutions. 33(8). pp.45-50, Institute of Industrial Engineers Publisher, United States 2001

[5] Del L. Younker. Value Engineering. Analysis and Methodol ogy, Marcel Dekker, Inc. Publisher, New York, 2003

[6] Department of Defense, Office of the Assistant Secretary of Defense, (acquisition and logistics). Value Engineering DOD 4245.8-H, March 1986

[7] Cristina Mihaela Gheorghe. Contributions on the cost and time reduction analysis necessary to the development of new solutions for the construction of induction motors", The PhD Thesis, 2012. (available only in Romanian)

[8] Cristina Mihaela Gheorghe, Mircea Covrig, Mihai Popescu. Characteristics of Value Analysis Method in Electrical Engineering, The 8th International Symposiom on Advanced Topics in Electrical Engineering, May 23-25, Bucharest, Romania, 2013

[9] Cezar Scarlat. Functionality-cost relationship. Value Engineering and Value Analisysis. In Financial Management. Printech Publisher, Bucharest, 2004 (available only in Romanian)

[10] Sunil Jauhar, Value Analysis in Galvanization Process: A cost Reduction Approach, Advances in Mechanical Engineering and its Applications (AMEA), vol. 2, no. 3, pp. $213-220,2012$
[11] Petru Orănescu. Value Analysis. Ştefan Gheorghiu Academy Publisher, Bucharest, 1979 (available only in Romanian)

[12] Florin Chichernea, Alexandru Chichernea. Value Analisys, Transilvania University Publisher, Brasov, 2010 http://www. scribd.com/doc/33629416/Analiza-Valorii-11-Curs-Autori-F lorin-Chichernea-Alexandru-Chichernea (July 2010)

[13] Matthew H. Johnson. Reconsidering Value Engineering: The Rhode Island School of Design Library Project. Civil Engineering. February 2007

[14] Michael Boock, May Chau The Use of Value Engineering in the Evaluation and Selection of Digitization Projects. Evidence Based Library \& Information Practice. 2(3). pp. 76-86, 2007.

[15] Mao, Xiaoming; Zhang, Xueqing. AbouRizk, Simaan M. Enhancing Value Engineering Process by Incorporating Inventive Problem-Solving Techniques. Journal of Construction Engineering and Management. May. pp.416-425, 2009

[16] M. J. Lee, J. K. Lim, G. Hunter. Performance-based value engineering application to public highway construction. KSCE Journal of Civil Engineering. 14(3), pp.261-27, 2010

[17] E.C.S. Kwok, P. M. Anderson, S.H.S. Ng. Value engineering for railway construction projects: cost driver analysis. Journal of Rail and Rapid Transit. 224(1), pp.45-52, 2010

[18] Habibollah Najafi, Amir Abbas Yazdani, Hosseinali Nahavandi. Value Engineering and Its Effect in Reduction of Industrial Organization Energy Expenses. World Academy of Science, Engineering and Technology, 62, 2010

[19] Marina Bădileanu. Energy prices and Value Analysis. Editura Economică, Bucharest, 2001, (available only in Romanian)

[20] Ioan Galea. Sports Ergonomy. Present stage and perspectives in the Romania. Conference of the sports performance. Arad, Romania, October, 2005, (available only in Romanian) http://www.sportscience.ro/html/articole_conf_2005_-_24.ht $\mathrm{ml}(29.09 .2010)$

[21] Mihaela Mariana Stancu, Studiul produsului farmaceutic prin analiza si ingineria valorii. PharmaBusiness, 2008 http://www.pharma-business.ro/oportunitati/studiul-produsul ui-farmaceutic-prin-analiza-si-ingineria-valorii.html (June 2009)

[22] Florin Chichernea, Alexandru Chichernea. Redesigning a Jaw Crusher Using Value Analysis. The Annals Of "Dunarea de Jos" University of Galati. Fascicle IX. Metallurgy and Materials Science. No. 1, 2009

[23] Aurelia-Sandală Aldea. Value Analysis. Designing/redesigni ng of an organization's management system Methods. AGIR Publisher, Bucharest, 2010 (available only in Romanian)

[24] *** STAS 11272/2-79 Value Analysis. The application of the method to the products (available only in Romanian)

[25] Chichernea, Florin. The optimization of the equipment design using the Value Engineering. Buletinul AGIR, no. 2, 2013 (in Romanian)

[26] Chichernea, Florin. The modular design of the industrial equipment. Buletinul AGIR, no. 2, 2013 (in Romanian)

[27] Chichernea, Florin. Value Analysis In Re-Design Of Industrial Equipment Buletinul AGIR, no. 1, 2010 